\title{
УДК 656.1:51-7
}

\section{А. О. ЧЕРНЕНКО ${ }^{1}$, Н. В. ХАЛІПОВА ${ }^{2}$, І. Ю. ЛЕСНІКОВА ${ }^{3} *$}

$1^{*}$ Каф. «Транспортні системи та технології», Університет митної справи та фінансів, вул. Вернадського, 2/4, 49044, м. Дніпро, Україна, тел. +38 (056) 756-05-57, ел. пошта Anastasiya.Bondarenko1 @ gmail.com, ORCID 0000-0003-2290-0627

$2^{2 *}$ Каф. «Транспортні системи та технології», Університет митної справи та фінансів, вул. Вернадського, 2/4, 49044, м. Дніпро, Україна, тел. +38 (056) 756-05-57, ел. пошта khalipov@rambler.ru, ORCID 0000-0001-5605-6781

$3^{*}$ Каф. «Транспортні системи та технології», Університет митної справи та фінансів, вул. Вернадського, 2/4, 49044, м. Дніпро, Україна, тел. +38 (056) 756-05-57, ел. пошта Lesnikova@i.ua, ORCID: 0000-0002-2750-6031

\section{ЩОДО МОДЕЛЮВАННЯ ТРАНСПОРТНИХ ПОТОКІВ ДЛЯ АНАЛІЗУ ЗАВАНТАЖЕНОСТІ ДОРІГ В МІСТАХ}

Метою дослідження є розвиток підходів до моделювання транспортних потоків в містах України, які розташовані на основних напрямках МТК з метою аналізу завантаженості доріг. Об'єктом дослідження виступають транспортні потоки на дорогах транспортної мережі; предметом дослідження - завантаженість елементів транспортної системи та характеристики транспортного руху. Методами дослідження прийнято моделювання $з$ застосуванням програмного продукту, що реалізований 3 використанням системи управління «CMS Drupal», заснованій на мові програмування PHP, мови програмування јavascript, елементів HTML, та CSS. Результатом дослідження $є$ аналітичний огляд використання інтелектуальних систем моделювання транспортних потоків, аналіз сучасних програмних продуктів для моделювання транспортних потоків. Здійснено моделювання транспортних потоків з використанням власної програми «Free way», яка дозволяє відслідковувати завантаженість доріг України на основі аналізу динаміки швидкості на обраних ділянках доріг. За основу програми прийнято програму «Яндекс. Пробки». Базова програма є зручною, але мітки, які можна створити за допомогою цієї програми, не зберігаються після перезавантаження сторінки та стають недоступними для інших користувачів. Метою програми «Free way» $\epsilon$ можливість створення «легких» міток $з$ рекомендаціями, які будуть зберігатися в базі даних і можуть обиратися з випадаючого списку. В статті наведені дані модельного експерименту з використанням програми «Free way» 3 метою дослідження завантаженості доріг України, що розташовані на основних напрямках міжнародних транспортних коридорів: Києва, Дніпра, Одеси та Львова. Для аналізу зміни швидкості руху обирали тільки з поміж тих вулиць, швидкість на яких в години «пік» протягом трьох діб не перевищувала 15 км/год. На основі даних реалізації модельного експерименту досліджено динаміку зміни швидкості транспортного потоку в різні часи доби. Наукова новизна полягає в представленні нового програмного продукту - програми «Free way», яка допомагає спростити моделювання транспортних потоків, удосконалити та розширити можливості спостереження і аналізу завантаженості доріг, швидкості руху транспортних засобів на основі діаграми динаміки зміни швидкостей. Реалізовано створення «легких» міток з рекомендаціями, які зберігаються в базі даних та назву яких можна обирати з випадаючого списку. Проаналізовано пропускну здатність окремих вулиць міст Києва, Дніпра, Одеси та Львова шляхом реалізації експериментального дослідження та побудови графіків динаміки швидкостей. В програмі реалізована можливість дослідження інших елементів транспортної системи та характеристик транспортного руху. Запропонований підхід доцільно розвивати в напрямку аналізу транспортної системи міст на наявність «вузьких місць». Це дозволить розробляти і реалізовувати заходи та приймати управлінські рішення щодо покращення ситуації на шляхах України.

Ключові слова: моделювання транспортних потоків, характеристики транспортного руху, діаграми динаміки зміни швидкостей

\section{Вступ}

Сучасна світова транспортна система переживає процес глибоких фундаментальних змін. В Європі інтеграційні процеси переведені в площину реалізації багатосторонніх масштабних проектів, істотно спрощена процедура перетину кордонів, створено численні міжнародні, міждержавні та громадські організації, які вивчають можливості і перспективи створення мереж міжнародних транспортних коридорів (MTК), покликаних з'єднати транспортними шляхами окремі міста або населені пункти в межах декількох країн, що являє принципово нову технологію переміщення пасажирів і вантажів від одного регіону на євроазійському континенті до іншого. МТК включає в себе присутність декількох видів транспорту на конкретно обраному напрямку з обов'язковою наявністю високо насиченої інфраструктури з їх обслуговування, сервісу, телекомунікацій, усіма видами сучасного зв'язку [1].

Створення МТК здійснюється у двох напрямках: перший - нове будівництво; другий -

(C) Черненко А. О., Халіпова Н. В., Леснікова I. Ю. 2016 
реконструкція та модернізація вже існуючих шляхів сполучення.

За умови зростання обсягів перевезень, зокрема міжнародних перевезень автомобільним транспортом, транспортна система України має бути готовою забезпечити міжнародні перевезення у повних обсягах. Якщо мережа міжнародних транспортних коридорів в Україні буде відповідати міжнародним вимогам, то це дасть змогу збільшити обсяги вантажопотоків по всіх основних напрямках коридорів, що проходять іiі територією.

Важливе значення для розвитку міжнародних транспортних коридорів має їх надійне та стабільне інформаційне забезпечення на базі сучасних засобів зв'язку і комп'ютерної техніки.

Великі міста, що розташовані на основних напрямках МТК, являють собою проблемні місця для проходження транспортних потоків та повинні враховуватися при плануванні руху транспорту. Крім економічних аспектів боротьби із заторами, доречним є розгляд інтелектуальних систем моделювання транспортних потоків. Дослідити і перевірити ефективність прийнятих планів можна за допомогою спеціальних програм, що моделюють транспортні потоки.

\section{Постановка проблеми у загальному вигляді та її зв'язок із важливими науковими та практичними завданнями}

Транспортні моделі міст використовуються в великих містах Європи, США, Азії, Сходу. Основні принципи створення транспортної моделі міста досліджуються в роботі [2].

Аналіз принципів та підходів до математичного моделювання транспортних потоків наведені в [3-6].

У минулому столітті для моделювання транспортних потоків використовувались математичні моделі, з якими працювали математики i інженери. Моделі носили теоретичний характер і не мали наочності, [7, 8].

Першим кроком відмови від класичного підходу стала спроба Карлоса Ф. Даганзо як основу вивчення транспортної динаміки розглянути роль звужень на дорогах, а елементарною одиницею моделювання щільних транспортних потоків вибрати чергу із транспортних засобів $[9,10]$.

В останні десятиріччя у дослідженнях транспортних потоків стали застосовувати міждисциплінарні математичні ідеї, методи й алгоритми нелінійної динаміки. Їх доцільність обгрун- тована наявністю в транспортному потоці стійких і нестійких режимів руху, втрати стабільності при зміні умов руху, нелінійних зворотних зв'язків, необхідністю великої кількості змінних для адекватного опису системи $[11,12$, 13].

3 розвитком інформаційних та комп'ютерних технологій інтегрований системний підхід в моделюванні транспортних процесів реалізується в програмних пакетах та застосовується транспортними проектувальниками для аналізу інформації про взаємодію транспортних засобів, затори, забруднення навколишнього середовища, тощо [14, 15].

За підрахунками Київської міськадміністрації, щодня в місті налічується до 70 заторів і тягучок. Причина заторів на київських дорогах хаотичне планування столиці. Київ і більшість великих міст України страждають від асиметрії - адміністративний, діловий та культурний центри сконцентровані в одній частині міста, на одному березі Дніпра, а спальні райони - на іншому. Ще одна причина заторів на дорогах високі темпи приросту кількості автомобілів у великих містах і низька пропускна спроможність українських доріг [16].

За кордоном $з$ проблемою заторів мешканці міст зіткнулися 15-20 років тому. Американці та японці боролися 3 ними за допомогою інженерних рішень: спорудження нових доріг і тунелів, багатоярусних транспортних розв'язок, паркінгів (підземних і на дахах будинків) [16].

Серед пропозицій щодо вирішення проблем заторів, пропонованих в [16], чільне місце відведено впровадженню інтелектуальних транспортних систем.

Розробки в області комп'ютерного програмного забезпечення для моделювання транспортних процесів та їх аналізу представляють сучасні програмні продукти, які стають потужним інструментом моделювання [9, 10].

Серед програмних комплексів для моделювання транспортних потоків розглянемо відомі програмні продукти - програми PTV Vision $®$ VISSIM та ArcGIS Traffic Analyst.

1. Програма PTV Vision $®$ VISSIM. В основі програмного забезпечення покладена німецька модель - сімейство програм ptv vision. Практично всі міста Німеччини 3 населенням понад 100 тис. чоловік користуються цим інструментом для вирішення транспортних завдань, також модель використовується в таких країнах як США, Англія, Ірландія, Голландія, Італія, Іспанія, Польща, Словаччина, Австрія, країни Близького Сходу й т.і. Основними компонен- 
тами системи ptv vision $є$ модуль VISEVA, моделі VISUM й VISSIM.

VISEVA була розроблена на кафедрі теорії планування транспортних потоків у Технічному університеті м. Дрездена і служить для обробки статистичної інформації. В результаті обробки будується матриця попиту на транспортне обслуговування (або матриця пересувань). Матриця пересувань $\epsilon$ основою для моделювання транспортної інфраструктури на рівні міст і регіонів та виконується за допомогою моделі VISUM. Основні завдання моделі - це планування транспортної інфраструктури й громадського транспорту; графічна обробка мережі; аналіз і оцінка транспортних мереж; прогноз запланованих заходів; створення платформи для транспортно-інформаційних систем.

При необхідності переходу на мікрорівень, тобто при плануванні руху на окремому перехресті чи групі перехресть або наочної демонстрації громадськості змін, які відбудуться в районі міста у випадку будівництва нових доріг, розв'язок і т.Д., застосовується модель VISSIM. Модель VISSIM застосовують для оцінки впливу типу перетинання доріг на пропускну здатність; проектування, тестування й оцінки впливу режиму роботи світлофора на характер транспортного потоку; оцінки транспортної ефективності запропонованих заходів; аналізу керування дорожнім рухом на автострадах і міських вулицях; аналізу впливу керування рухом на ситуацію в транспортній мережі; аналізу пропускної здатності більших транспортних мереж при динамічному перерозподілі транспортних потоків; аналізу заходів по регулюванню руху в залізничному транспорті й при організації стоянок очікування; детальної імітації дій кожного учасника руху; моделювання зупинок громадського транспорту й станцій метрополітену. Розрахунок аналітичних показників дає більше ніж 50 різних оцінок і аналітичних коефіцієнтів, можливість побудови графіків завантаження мережі й т.п. [13, 17].

2. Програма ArcGIS Traffic Analyst. Серед технологій, які забезпечуються програмою модуль розширення для системи ArcGIS, призначений для планування руху транспорту. Модуль Traffic Analyst перетворює комплекс ArcGIS у повнофункціональну систему планування транспортних потоків. Основу Traffic Analyst становить набір передових інструментів моделювання, що підключають до середовища обробки геопросторових даних ArcGIS Geoprocessing, доповнений спеціалізованими інструментами редагування для роботи 3 маршрутами й розкладами громадського транспорту.

Користувачі можуть створювати складні моделі руху транспорту, використовуючи додаток ArcGIS Model Builder й інструменти Traffic Analyst, які можуть вільно сполучатися з іншими інструментами обробки геопросторових даних. Тісна інтеграція інструментів моделювання транспортних потоків із системою ArcGIS дозволяє користувачам Traffic Analyst ефективно застосовувати функціональні можливості ArcGIS для візуалізації, редагування, керування даними й т. і. при плануванні руху транспорту.

Модуль Traffic Analyst включає інструменти, необхідні для підтримки процесів прийняття рішень при плануванні руху транспорту, надаючи фахівцям із планування можливість виконувати великий спектр завдань, як то: прогнозування транспортних потоків; аналіз доступності транспортних засобів; моделювання змін попиту на транспортні перевезення, викликані змінами в інфраструктурі, землекористуванні, політиці, демографії і т.д.; оцінка наслідків великих інфраструктурних проектів; формування основи для оцінки екологічного впливу змін у транспортних системах.

Функціональні можливості модуля Traffic Analyst включають інструменти обробки геопросторових даних, необхідних для моделювання транспортних потоків, і надає можливість користувачам ArcGIS/Traffic Analyst створювати й застосовувати передові моделі руху транспорту в інтуїтивно зрозумілому, гнучкому й продуктивному середовищі ArcGIS. Модуль Traffic Analyst пропонує інструменти для: моделювання формування та розподілу транспортних потоків; розщеплення на різні режими транспортних перевезень; базових операцій 3 матрицями; визначення завантаження автотранспортної мережі; визначення завантаження мережі громадського транспорту; редагування даних про громадський транспорт [18].

\section{Визначення мети та задачі дослідження}

Для України на сьогодні гостро постає питання створення ринку проектів транспортного моделювання $[19,20]$. Особливо важливим дане завдання є для міст, що знаходяться на основних напрямках МТК (коридор № 5, що не має конкуренції в залученні вантажів; коридори № 9, № 3, конкуренцію яким складають російські коридори).

Питання можна вирішити шляхом: запровадження транспортного моделювання на всіх рівнях, створення нормативної бази для транспо- 
ртного моделювання та подальшої розробки та створення транспортних моделей міст України [2].

На першому кроці необхідно розглянути транспортний вузол на макрорівні, встановити фактори, що впливають на виникнення заторів і виявити закони цього явища.

Далі має бути моделювання ситуації на мікрорівні та встановлення ролі окремої розв'язки на мережі і ¥ї вплив на формування заторів у місті.

Досвід європейських країн та Сполучених Штатів у питанні моделювання транспортних потоків показує, що в кожній країні підходи до питання моделювання i, тим самим, зменшення заторів у містах - свої.

Розглянуті вище сучасні програмні продукти для моделювання транспортних потоків, такі як PTV Vision ${ }^{\circledR}$ VISSIM та ArcGIS Traffic Analyst, є потужним інструментом моделювання транспортних потоків як на макро, так і на мікрорівні. Вони дозволять візуалізувати транспортні потоки в масштабах як всього міста, так і окремої розв'язки та мають стати логічним розвитком підходів, що базуються на експертних оцінках, інженерних розрахунках та теоретичних математичних моделях.

Кожне 3 великих міст Європи, США, Азії, Сходу має одну, а іноді й декілька власних транспортних моделей. Наприклад, програму «PTV VISUM» використовують при створенні транспортних моделей міст СНГ, Нью-Йорку, Берліну, Мюнхену, Шанхаю. Ринок клієнтів PTV Partner представлено на рис. 1.

Дана стаття присвячена актуальній проблемі моделювання транспортних потоків в містах України, які розташовані на основних напрямках МТК з метою аналізу завантаженості доріг. Для даного дослідження оберемо такі транзитно-важливі міста, як Дніпро, Київ, Львів та Одеса.

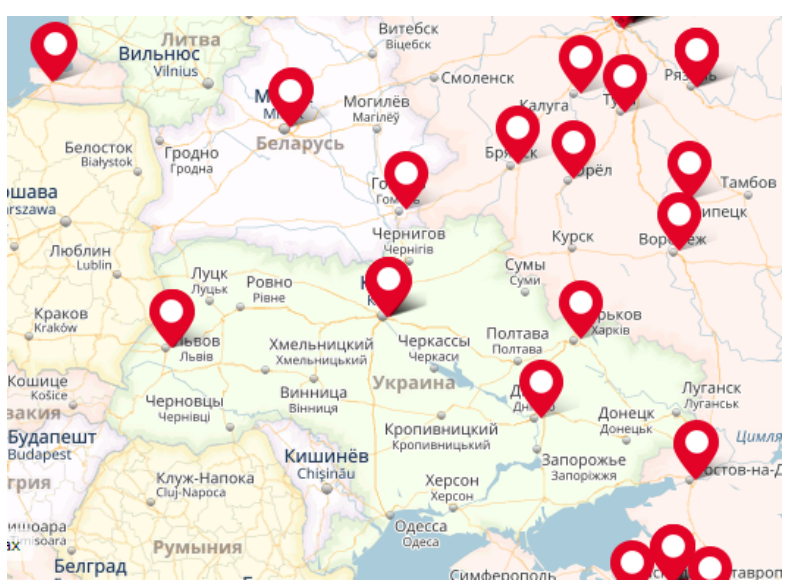

Рис. 1. Клієнти PTV Partner

\section{Основна частина дослідження}

Моделювання транспортних потоків проведено із застосуванням власної програми «Free way», яка дозволяє, по-перше, спростити процес моделювання транспортних потоків, подруге, удосконалити та розширити можливості спостереження та аналізу завантаженості доріг. За основу програми прийнято програму «Яндекс. Пробки», завдяки якій є можливість бачити завантаженість та швидкість руху транспортного потоку на обраних ділянках доріг України. Базова програма («Яндекс. Пробки») є зручною, але має суттєвий недолік - мітки, які можна створити за допомогою цієї програми не зберігаються після перезавантаження сторінки, а це означає, що вони стають недоступними для користувачів.

Метою програми «Free way» $\epsilon$ можливість створення «легких» міток з рекомендаціями таких, що будуть зберігатися в базі даних та назву яких можна буде обирати 3 випадаючого списку. Програма дозволяє аналізувати швидкості руху транспортних засобів в потоці на основі діаграми динаміки зміни швидкостей.

Для створення даної програми використано систему управління «CMS Drupal», яка заснована на мові програмування РНР, мову програмування javascript, елементи HTML, тa CSS.

Алгоритм виконання завдання складається 3 декількох кроків:

- налаштувати середовище за допомогою багатоплатформної збірки веб-сервера XАМРP, що містить Apache, MySQL, інтерпретатор скриптів PHP, мову програмування Perl та велику кількість додаткових бібліотек, що дозволяють запустити повноцінний веб-сервер;

- скопіювати тіло програми в каталог XAMPP;

- створити базу даних та імпортувати дані 3 файлу «freeway.sql»;

- запустити програму, за адресою localhost/freeway у браузерi;

- сформувати новий об'єкт карту, при необхідності додати мітки, обрати масштаб та центр карти;

- зберегти карту в базі даних, завдяки чому до неї можна буде звернутися в будь-який час та відредагувати, шляхом додавання або видалення міток.

Алгоритм програми «Free way» представлений на рис. 2. 


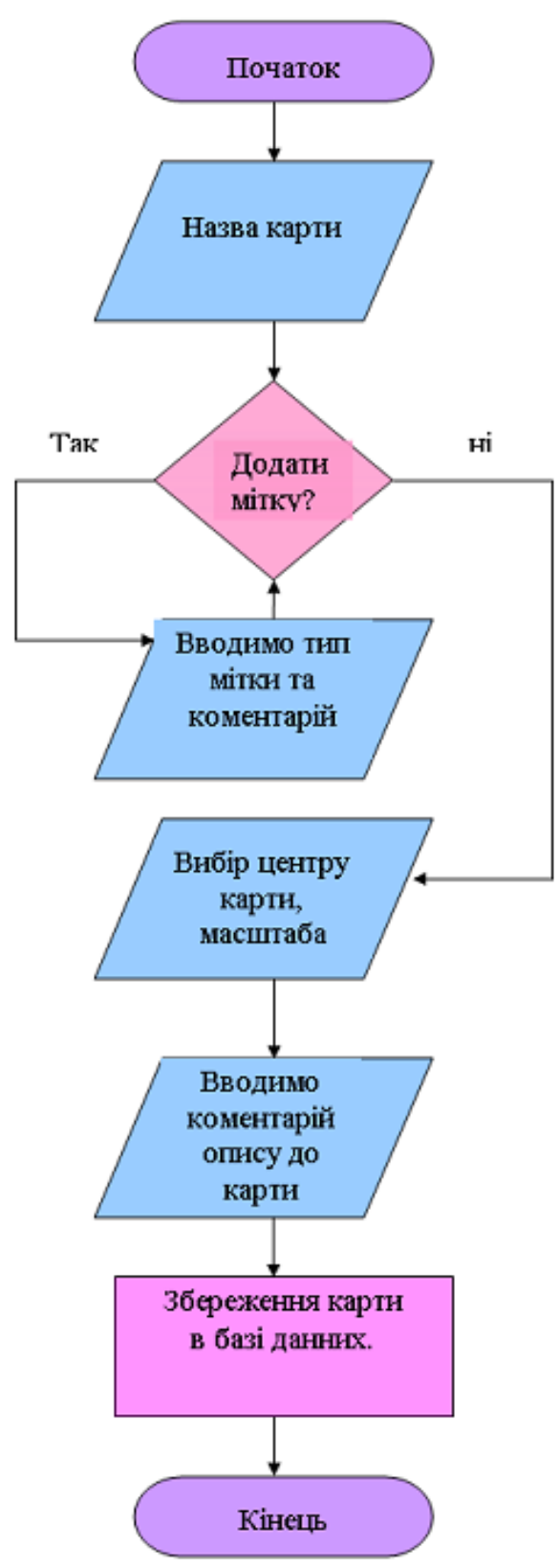

Рис. 2. Алгоритм програми «Free way»

Тепер більш детально опишемо процес додавання мітки:

1) Заходимо на сторінку редагування карти.

2) Користувач клікає по карті в потрібному йому місці, де повинна знаходитися майбутня мітка, а потім у формі, що відкрилася обирає 3 випадаючого списку іï найменування та додає коментар до неї. Таким чином можна додати будь-яку кількість міток.

3) В наступному полі «Body» можна додати загальний коментар для карти, який буде відображений на сторінці карти.

4) Обравши потрібний масштаб та центр карти, натискаємо кнопку «Save», після чого користувач автоматично направляється на сторінку новоствореної карти. На сторінці карти у ко- ристувача з'являється можливість проаналізувати завантаженість доріг, використовуючи функції сервісу Yandex. (Пробки). Сама карта з'являється в таблиці всіх карт.

Алгоритм реалізований у вигляді програмного продукту, що використовується на кафедрі транспортних систем та технологій Університету митної справи та фінансів при проведенні наукових досліджень.

Результат виконання коду, що відповідає за відображення карти 3 елементами управління наведений на рис. 3 .

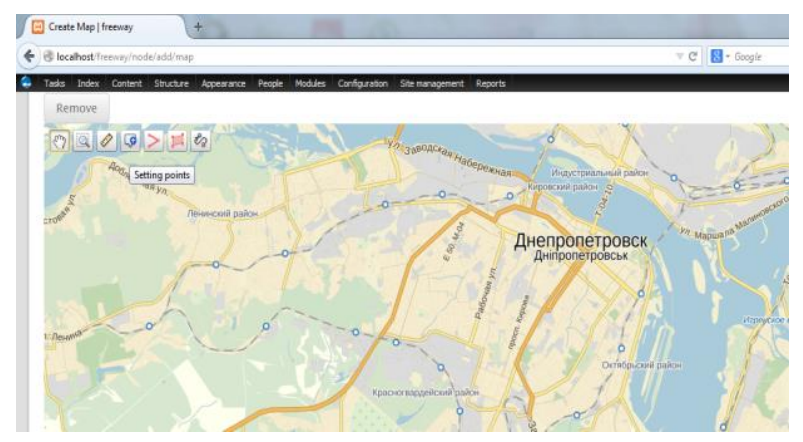

Рис. 3. Результат виконання коду, що відповідає за відображення карти $з$ елементами управління

Результат виконання коду побудови форми створення мітки та нанесення iii на карту наведений на рис. 4.

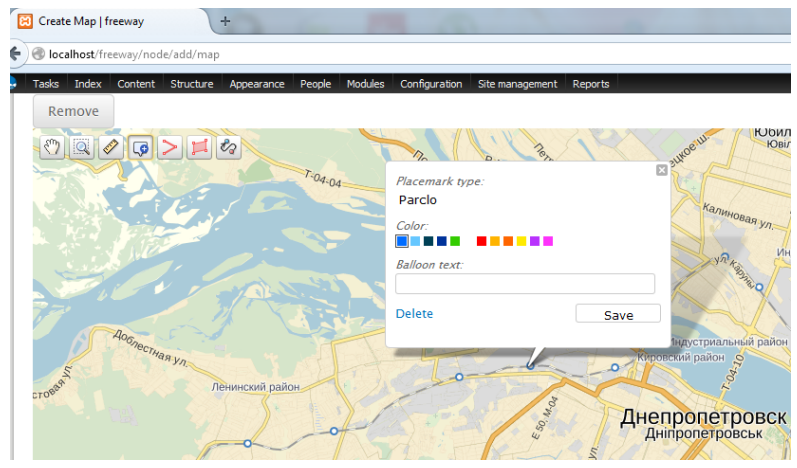

Рис. 4. Результат виконання коду побудови форми створення мітки та нанесення ii на карту

Для аналізу руху транспорту будуються графіки динаміки швидкостей. Результатом виконання даного коду є графічне подання залежності зміни швидкості руху від часу.

В червні 2014 року був проведений експеримент 3 використанням програми «Free way» 3 метою дослідження завантаженості доріг України в транзитно-важливих містах, як Дніпро, Київ, Львів та Одеса. На графіках (рис. 5-8) представлена залежність швидкості транспортних засобів від часу в цих містах. Для аналізу зміни швидкості руху протягом доби обирали тільки 3 поміж тих вулиць, швидкість на яких в години «пік» за три доби не перевищувала 15 км/год. 


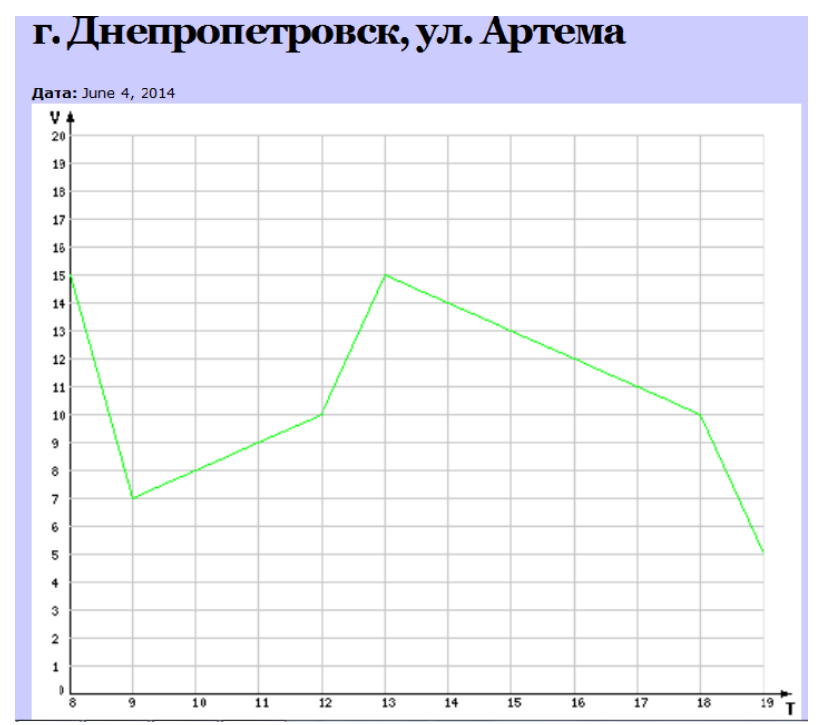

Рис. 5. Аналіз зміни швидкостей руху (м. Дніпро, вул. Січових Стрільців (вул. Артема))

\section{г. Києв, УЛ. Бархатная}

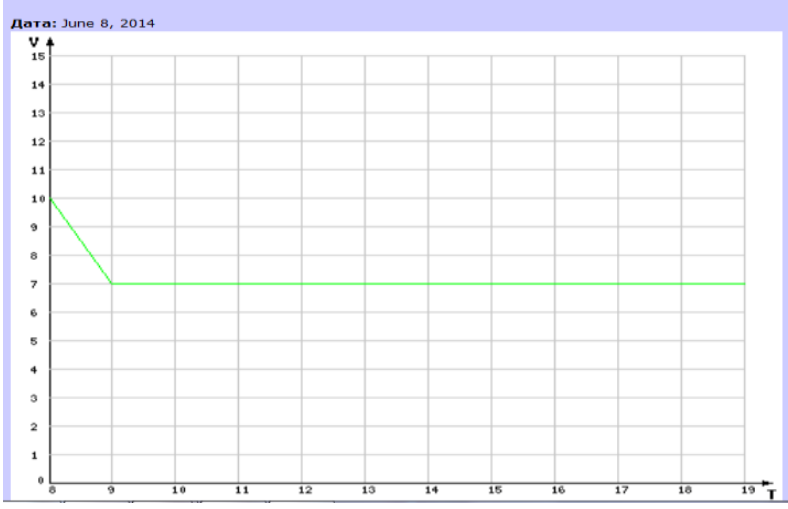

Рис. 6. Аналіз зміни швидкостей руху (м. Київ, вул. Оксамитова)

\section{г. Одесса, ул. Канатная}

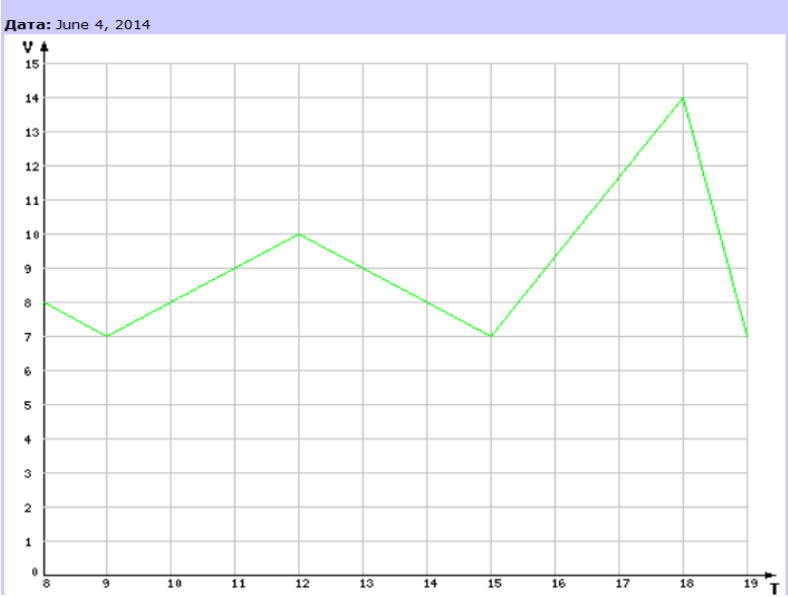

Рис. 7. Аналіз зміни швидкостей руху (м. Одеса, вул. Канатна)

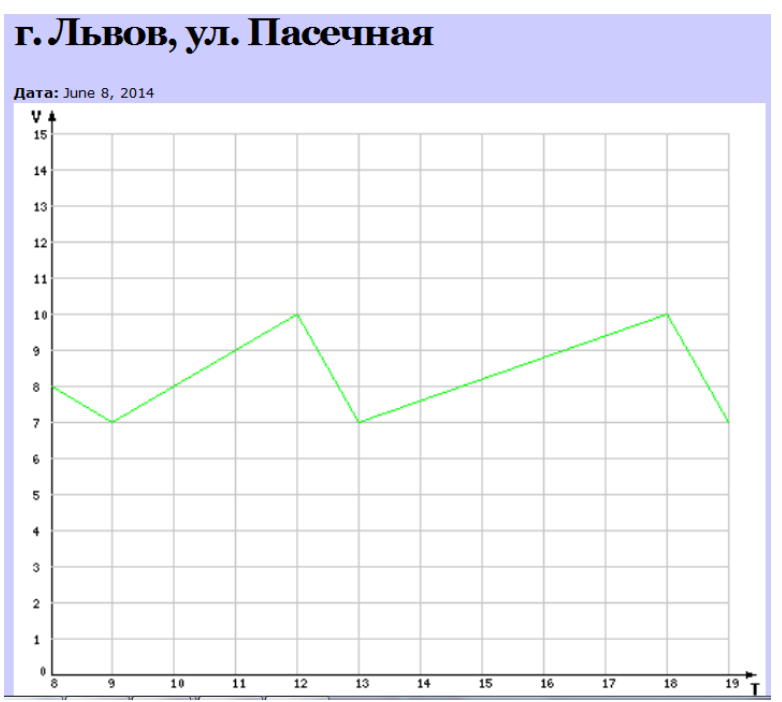

Рис. 8. Аналіз зміни швидкостей руху (м. Львів, вул. Пасічна)

Наприклад, для аналізу пропускної здатності вулиць Дніпропетровську (Дніпра) обрали вулицю Артема (вул. Січових Стрільців). Швидкість на обраній вулиці в години - «пік» протягом трьох діб не перевищувала 15 км/год.

3 графіка (рис. 5) бачимо, що зниження швидкості спостерігається майже протягом всього дня, не тільки в години - «пік» (8:00 9:00), а і з 13:00 до 19:00 включно.

Для аналізу пропускної здатності вулиць Києва оберемо вулицю Оксамитову (Бархатная). Швидкість на обраній вулиці в години «пік» протягом трьох діб не перевищувала 10 км/год (рис. 6). Дана вулиця є однією 3 центральніх вулиць, рух по яким $є$ дуже ускладненим.

Для аналізу пропускної здатності вулиць Одеси оберемо вулицю Канатну. Швидкість на обраній вулиці в години - «пік» протягом трьох діб не перевищувала 14 км/год. На графіку (рис. 7) спостерігається очікувана залежність швидкості від часу доби - в часових інтервалах: 8:00 - 9:00, 12:00 - 15:00, 18:00 - 19:00 спостерігається зниження швидкості руху.

Аналогічно проаналізуємо «проблемні» вулиці Львова. Оберемо вулицю Пасічну. Швидкість на обраній вулиці в години - «пік» протягом трьох діб не перевищувала 10 км/год. На графіку (рис. 8) спостерігається абсолютно логічне зменшення швидкості руху в часи - «пік» $(8: 00$ - 9:00, 12:00 - 13:00, 18:00 - 19:00) та навпаки збільшення у інший час.

Однією зі зручних можливостей програми $\epsilon$ одночасне порівняння до семи графіків руху. Графік порівняння представлений на рис. 9. 

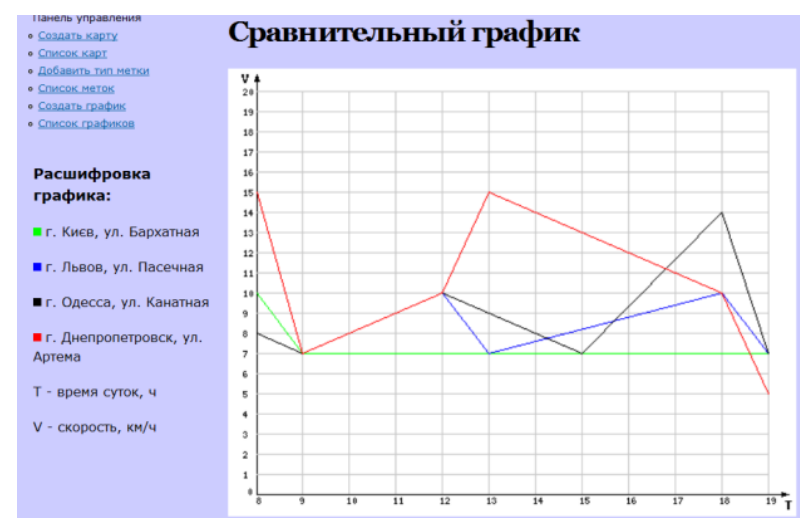

Рис. 9. Порівняння графіків аналізу зміни швидкостей

В даному проекті на прикладі окремих вулиць представлена група інших вулиць, аналогічних за характером транспортного руху.

3 даного графіка видно, що найускладненішим є рух в Києві на вулиці Оксамитова (Бархатная).

\section{Висновки з дослідження і перспективи, подальший розвиток у даному напрямку}

В статті представлено новий програмний продукт - програму «Free way», яка дозволяе спростити моделювання транспортних потоків, удосконалити та розширити можливості спостереження та аналізу завантаженості доріг. Реалізовано створення «легких» міток 3 рекомендаціями, які зберігаються в базі даних та назву яких можна обирати з випадаючого списку.

Проаналізовано пропускну здатність вулиць міст Києва, Дніпра, Одеси та Львова, шляхом реалізації експериментального дослідження та побудови графіків динаміки швидкостей.

В програмі реалізована можливість дослідження інших елементів транспортної системи та характеристик транспортного руху.

Запропонований підхід доцільно розвивати в напрямку аналізу транспортної системи міст на наявність «вузьких місць». Це дозволить розробляти і реалізовувати заходи та приймати управлінські рішення щодо покращення ситуації на шляхах України.

\section{БІБЛІОГРАФІЧНИЙ СПИСОК}

1. Бакаев, А. А. Международные транспортные коридоры Украины: сети и моделирование / А. А. Бакаев та ін. - Київ : КУЭТТ, 2003 - С. 7-14.

2. Осєтрін, М. М. Основні принципи створення транспортної моделі міста [Електрон. ресурс] / М. М. Осєтрін, Д. О. Беспалов, М. І. Дорош // Режим доступу : https://bespalov.me/

3. Семёнов, В. В. Исторический анализ моделирования транспортных процессов и транспортной инфраструктуры [Электрон. ресурс] / В. В. Семёнов, А. В. Ермаков // Препринты ИПМ им. М.В.Келдыша. - 2015. - № 3. - 36 с. Режим доступпу: /preprint. asp?id=2015-3 URL:http://library.keldysh.ru

4. Халіпова, Н. В. Оптимізація пасажирських перевезень у вузлах мегаполісів / Н. В. Халіпова, І. Ю. Леснікова // Системи та технології. - 2016. - Вип. 1. - C. $55-69$.

5. Скалозуб, В. В. Моделирование неоднородных транспортных потоков с переменными тарифами / В. В. Скалозуб, Л. А. Паник // Транспортні системи та технології перевезень. - 2015. - Вип. 10. - С. 105112.

6. Козаченко, Д. Н. Моделювання розподілу вантажопотоків на напрямках транзитних перевезень залізничним транспортом у міжнародному сполученні / Козаченко Д. Н., Гера Б. В., Скалозуб В. В., Германюк Ю. Н. // Транспортні системи та технології перевезень. - 2016. - Вип. 11. - С. 39-47.

7. Atkins, S. Transportation planning models: What the papers say // Traffic Engineering and Control. 1986. - Vol. 27, - № 9.

8. Беспалов, Д. Методы моделирования транспортных потоков [Электрон. ресурс] / Д. Беспалов // Режим доступу : https://bespalov.me/2012/07/16/ metody-modelirovaniya-transportnyh-potokov/

9. Daganzo, C. F. Macroscopic Relations of Urban Traffic Variables: Bifurcations, Multivaluedness and Instability / C. F. Daganzo, V. Gayah, E. Gonzales // Transportation Research Part B: Methodological. 2011. - 45(1). - P. 278-288.

10. Daganzo, C. F. Fundamentals of transportation and traffic operations. N.Y. : Elsevier Science Inc., 1997.

11. Киселев, А. Б. Моделирование автотранспортных потоков методами механики сплошной среды / А. Б. Киселев и др. // Ломоносовские чтения : Научная конф. Секция механики. Апрель 2007 г.. - Москва : Изд-во Моск. ун-та, 2007.

12. Семенов, В. В. Математическое моделирование динамики транспортных потоков мегаполиса / В. В. Семенов // Автомобильный транспорт. - 2010. - № 3. - C. 4.

13. PTV Vision ${ }^{\circledR}$ VISSIM - имитационное моделирование транспортной ситуации на перекрестках и развязках [Электрон. ресурс]. - Режим доступу: http://www.ptv - vision.ru/

14. Weiner, Ed and Fred Ducca. «Upgrading Travel Demand Forecasting Capabilities», ITE Journal, Volume 69, Number 7, July 1999. - PP. 28-33.

15. Kane, L. Transport planning models - an historical and critical review / Kane L., R. Behrens // Urban Transport Research Group, University of Cape Town - [Электрон. ресурс]. - Режим доступу : http://repository.up.ac.za/bitstream/ handle/2263/7834/037.pdf?sequence $=1$.

16. Руденко, В. Дорогі дороги / В. Руденко, О. Шкарпова // Контракти : Український діловий тижневик. - 2007. - № 46 від 12.11.2007.

17. Якимов, М. Р. Транспортное планирование: 
практические рекомендации по созданию транспортных моделей городов в программном комплексе PTV Vision ${ }^{\circledR}$ VISUM: монография / М. Р. Якимов, Ю. А. Попов. - Москва : Логос, 2014. - 200 с. - Режим доступу : http://ut.nmu.org.ua/ua/ptv/2 Якимов Практические рекомендации по созданию транспортних моделей в Vissum.pdf.

18. Геоинформационный портал ГИС - Ассоциации [Электрон. ресурс]. - Режим доступу: http://www.gisa.ru

19. Интеллектуальные транспортные системы проблемы на пути внедрения в России [Электрон. pecypc]. - Режим доступу : https://habrahabr.ru/post/175497/
20. Маркелов, В. М. Интеллектуальные транспортные системы как инструмент управления [Электрон. ресурс] / В. М. Маркелов, И. В. Соловьев, В. Я. Цветков // Государственный советник. - 2014. Вып. 3 (7). - Режим доступу : http://cyberleninka.ru/ article/n/intellektualnye-transportnye-sistemy-kakinstrument-upravleniya

Стаття рекомендована до публікаиії д.физ.-мат.н., проф. Пасічником А. М. (Україна)

Надійшла до редколегії 29.11.2016. Прийнята до друку 30.11.2016.

\section{А. О. ЧЕРНЕНКО, Н. В. ХАЛИПОВА, И. Ю. ЛЕСНИКОВА}

\section{К ВОПРОСУ МОДЕЛИРОВАНИЯ ТРАНСПОРТНЫХ ПОТОКОВ С ЦЕЛЬЮ АНАЛИЗА ЗАГРУЖЕННОСТИ ДОРОГ В ГОРОДАХ}

Целью исследования является развитие подходов к моделированию транспортных потоков в городах Украины, которые расположены на основных направлениях МТК с целью анализа загруженности дорог. Объектом исследования выступают транспортные потоки на дорогах транспортной сети; предметом исследования - загруженность элементов транспортной системы и характеристики транспортного движения. Методом исследования является моделирование с использованием программного продукта, реализованного на базе системы управления «CMS Drupal», основанной на языке программирования РНР, языка программирования javascript, элементов HTML, и CSS. Результатом исследования является аналитический обзор использования интеллектуальных систем моделирования транспортных потоков, анализ современных программных продуктов для моделирования транспортных потоков. Осуществлено моделирование транспортных потоков с использованием собственной программы «Free way», которая позволяет отслеживать загруженность дорог Украины на основе анализа динамики скорости на выбранных участках дорог. За основу программы принята программа «Яндекс. Пробки». Базовая программа является удобной, но метки, которые можно создать с ее помощью, не сохраняются после перезагрузки страницы и становятся недоступными для других пользователей. Целью программы «Free way» является возможность создания «легких» меток с рекомендациями, которые будут сохраняться в базе данных и могут выбираться из выпадающего списка. В статье приведены данные модельного эксперимента с использованием программы «Free way» с целью исследования загруженности дорог Украины, расположенных на основных направлениях международных транспортных коридоров: Киева, Днепра, Одессы и Львова. Для анализа изменения скорости движения выбраны те из улиц, скорость движение на которых в час «пик» в течение трех суток не превышала 15 км/ч. На основе данных реализации модельного эксперимента исследована динамика изменения скорости транспортного потока в разное время суток. Научная новизна заключается в представлении нового программного продукта - программы «Free way», которая помогает упростить моделирование транспортных потоков, усовершенствовать и расширить возможности наблюдения и анализа загруженности дорог, скорости движения потока транспортных средств на основе диаграммы динамики изменения скоростей. Реализовано создание «легких» меток с рекомендациями, которые сохраняются в базе данных и название которых можно выбирать из выпадающего списка. Проанализирована пропускная способность отдельных улиц Киева, Днепра, Одессы и Львова на основе реализации экспериментального исследования и построения графиков динамики скоростей. В программе реализована возможность исследования других элементов транспортной системы и характеристик транспортного движения. Предложенный подход целесообразно развивать в направлении анализа транспортной системы городов на наличие «узких мест». Это позволит разрабатывать и реализовывать мероприятия и принимать управленческие решения относительно улучшения ситуации на дорогах Украины.

Ключевые слова: моделирование транспортных потоков, характеристики транспортного движения, диаграммы динамики изменения скоростей

\section{A. O. CHERNENKO, N. V. HALIPOVA, I. Y. LESNIKOVA}

\section{TRAFFIC LOAD ANALYSIS BASED ON TRAFFIC FLOWS MODELING}

The purpose of the study is to develop approaches to the modeling of traffic flows in the cities of Ukraine, 
which are located on the main directions of ITC in order to analyze the traffic congestion. The object of the study are the traffic flows on the roads network; subject of study - the load of transport system elements and traffic characteristics. Research methods is the simulation using the software implemented on the basis of «CMS Drupal» management system based on PHP programming language, JavaScript programming language, HTML elements, and CSS. The result of the study is analytical overview of the traffic flows modeling intelligent systems' usage, analysis of modern software products for traffic flows modeling. Performed modelling of traffic flows using own software «Free Way», which allows to monitor the loads of roads in Ukraine based on the analysis of speed dynamics on selected road sections. As the basis of the program adopted «Yandex. Traffic Jams». The basic program is convenient, but the labels that you can create with it are not saved after the page refresh and are no more available to other users. The purpose of the program «Free Way» is to create "light" labels with the recommendations, which will be stored in a database and can be selected from the dropdown list. The article presents the data of model experiment using the program «Free way» to study congestion of roads in Ukraine, located on the main directions of the international transport corridors: Kiev, Dnepropetrovsk, Odessa and Lviv. To analyze the changes in the velocity of the selected the streets, the speed of the movement in which in «peak» hour for three days does not exceed $15 \mathrm{~km} / \mathrm{h}$. On the basis of data model experiment's realization, investigated the dynamics of changes in traffic speeds at different times of the day. Scientific novelty is in presentation of the new software product - the "Free Way" software, which helps to simplify the modeling of traffic flows, improve and enhance the ability of observation and analysis of the traffic congestion, vehicle flow speed based on the rates of change in the dynamics of the speeds. Implemented creation of "light" labels with the recommendations, which are stored in the database and the name of which can be selected from the drop-down list. Performed the capacity analysis of individual streets of Kiev, the Dnieper, Odessa and Lviv based on a pilot study and charting of speeds dynamics. The program features the ability to study other elements of the transport system and traffic characteristics. The proposed approach is reasonable to develop in the direction of the city transport system analysis for the presence of «bottlenecks». This will develop and implement actions and make management decisions on how to improve the situation on the roads of Ukraine.

Keywords: traffic flows modeling, traffic characteristics, rates of change in the dynamics of speeds. 